\title{
A Study Comparing the Characteristics of Zinc Oxide Eugenol-Based and Mineral Trioxide Aggregate-Based Root Canal Sealers
}

\author{
Seok-Eun Lee ${ }^{1}$, Ja-Won Cho', Hyun-Jun Yoo' ${ }^{1}$ Myung-Gu Lee ${ }^{2}$, Yeol-Mae Jeon ${ }^{1}$, Da-Hui Kim², \\ Hye-Won Park ${ }^{1}$ \\ ${ }^{1}$ Department of Preventive Dentistry, College of Dentistry, Dankook University, Cheonan, ${ }^{2}$ Department of Biomedical \\ Chemistry, College of Biomedical \& Health Science, Konkuk University, Chungju, ${ }^{3}$ Department of Dental Hygiene, \\ College of Health Science, Dankook University, Cheonan, Korea
}

Objective: This study aimed to investigate the antimicrobial activity and cytotoxicity of zinc oxide eugenol (ZOE)-based and mineral trioxide aggregate (MTA)-based root canal sealers.

Methods: The root canal sealers used in this study were Tubli-Seal (a ZOE-based sealer) and ProRoot (an MTA-based sealer). The antimicrobial activity of ProRoot and Tubli-seal was assessed using a susceptibility assay using Enterococcus faecalis, Porphyromonas endodontalis, and Porphyromonas gingivalis. The cytotoxicity of the root canal sealers was investigated using MTT assay, real-time RT-PCR, and ELISA after the pulp cells were treated with sealers. Additionally, the components of the root canal sealers were analyzed using X-ray fluorescence.

Results: The MTA-based sealer showed stronger antimicrobial activity against $E$. faecalis than the ZOE-based sealer, and the antimicrobial activities of both sealers against $P$. endodontalis and $P$. gingivalis were not significantly different. The ZOE-based sealer showed strong cytotoxicity towards pulp cells and induced the expression and production of inflammatory cytokines. However, the MTA-based sealer did not affect the viability of pulp cells or significantly induce the expression of inflammatory cytokines such as TNF- $\alpha$, IL- 6 , and IL-8. In the component analysis, the MTA-based sealer had more kinds of metal oxides than the ZOE-based sealer.

Conclusion: The MTA-based sealers had stronger antimicrobial activity against $E$. faecalis compared to the ZOE-based sealer, and did not show significant cytotoxicity towards pulp cells. Based on these results, MTA-based sealers may be a suitable material for root canal therapy.

Keywords: mineral trioxide, root canal, sealers, zinc oxide eugenol

Corresponding author Hye-Won Park

E-mail: dkuprev@gmail.com

(iD) https://orcid.org/0000-0001-9590-2442

Received July 15, 2021, Revised September 27, 2021, Accepted September 29, 2021

*This article is an excerpt from Seok-Eun Lee's 2020 doctoral thesis.

\section{Introduction}

Pulpitis is induced by microbial infections in the root canal system [1]. Most microbial infections in the root canal system occur and progress when the root canal system is exposed to the oral environment by tooth cracks, tooth fractures, or severe

Copyright (C) 2021. Korean Academy of Preventive Dentistry. All rights reserved.

This is an Open Access article distributed under the terms of the Creative Commons Attribution Non-Commercial License (http://creativecommons.org/licenses/ by-nc/4.0) which permits unrestricted non-commercial use, distribution, and reproduction in any medium, provided the original work is properly cited. 
caries [2]. Therefore, the treatment of pulpitis involves removing caries, restoring the damaged tooth, and performing root canal therapy [3,4]. In the case of reversible pulpitis, after extracting the root nerves, the root canal system is cleaned and filler inserted to prevent re-infection with bacteria [5]. Therefore, the success of root canal therapy depends on cleaning, shaping, and sealing the root canal system, as well as microbial control. However, it is difficult to completely eliminate microbes in the root canal system because the root canal system is anatomically complex, having fins, isthmi, and accessory canals [6-8]. For these reasons, root canal sealers with antimicrobial activity have been studied and developed.

The main function of root canal sealers is to fill the space between the dentin wall and the gutta-percha cone as a root canal obturation material $[9,10]$. Root canal sealers have been categorized according to their composition, and include epoxy resin (ER)-based, silicon-based, methacrylate resin (MR)-based, calcium-phosphate (CP)-based, zinc oxide eugenol (ZOE)-based, and mineral trioxide aggregate (MTA)based sealers [11-15]. Among these, ZOE-based sealers have been used the longest, and MTA-based sealers have only recently been developed. ZOE-based sealers combine zinc oxide powder with liquid eugenol [16], and the most valuable component of the ZOE sealer is zinc oxide, which is stably crystallized in a hexagonal wurtzite structure [17].

Although $\mathrm{Zn}$ is an essential element for cells, at an essential threshold level, it inhibits bacterial enzymes such as dehydrogenase, thiol peroxidase, and glutathione reductase [18]. In addition, metal oxide compounds damage the cell wall of bacteria, increasing the permeability of molecules into the cytoplasm [19]. Eugenol is an essential oil from Cymbopogon citrates, an aromatic plant, and has antioxidant, anti-spasmodic, and antimicrobial activities [20,21]. MTA-based sealers are bioceramic and composed of calcium oxide and silicon dioxide [22]. When both components are mixed, they produced tricalcium silicate, dicalcium silicate, tricalcium aluminate, and tetracalcium aluminoferrite [22]. Commercial MTA-based sealers exist in both gray and white forms. The white MTAbased sealer lacks iron, compared to the gray MTA-based sealer [23].

Porphyromonas gingivalis and Porphyromonas endodontalis have been most frequently isolated from necrotic pulp [24,25]; therefore, both bacteria are considered to be associated with initial infection of the root canal. P. gingivalis is better known as a periodontopathogen than as pulpitis-related bacteria. $P$. gingivalis and $P$. endodontalis are classified as small, gram-negative, black-pigmented anaerobes [26]. Both bacteria have various enzymes such as arginine proteinases, cysteine proteinases, and lysine proteinases [27,28] and lip- opolysaccharides $[29,30]$. These virulence factors induce tissue destruction and inflammatory cytokines in gingival tissue, resulting in apical periodontitis (pulpitis) and acute periodontitis. Enterococcus faecalis has been detected in apical periodontitic lesions during root canal treatment failure [31]. This bacterium has been characterized as a gram-positive facultative anaerobe, and its virulence factors include cytolysin, gelatinase, adhesion, enterococcal surface protein, and lipoteichoic acid [32]. Furthermore, E. faecalis has various antibiotic resistance genes [33]. Due to these characteristics, $E$. faecalis may live in extreme environments, such as root canal-treated teeth.

The purpose of this study was to investigate the antimicrobial activities of ZOE-based sealer, as a conventional root canal sealer, and MTA-based sealer, as a recently developed root canal sealer. In addition, the biocompatibility and physical properties of both sealers were evaluated using pulp cell, Vickers hardness instrument, and X-ray fluorescence (XRF) analyses.

\section{Materials and Methods}

\section{Preparation of root canal sealers}

The sealers used in this study were Tubli-Seal ${ }^{\mathrm{TM}}$ (Kerr Co., Orange, CA, USA), as a ZOE-based sealer, and ProRoot MTA (Dentsply Sirona, York, PA, USA), as an MTA-based sealer. In order to investigate antimicrobial activity and cytotoxicity, both sealers $(200 \mathrm{mg}$ ) were placed into each well of a 12-well polystyrene plate (SPL Lifescience, Gyeonggi, Republic of Korea), and $1 \mathrm{ml}$ of phosphate buffered saline (PBS; pH, 7.2) containing $10 \%$ dimethyl sulfoxide (DMSO) was added. The microplate was incubated on a shaker for $6 \mathrm{~h}$ at room temperature to extract the sealer components before setting. In addition, the sealers were placed into each well of a 12 -well polystyrene plate, and sterile distilled water was dispensed into the outside well of a 12-well plate to support a humidified condition. The plates were then incubated for $24 \mathrm{~h}$ at $37^{\circ} \mathrm{C}$ to set the sealer.

\section{Bacterial strain and cultivation}

Porphyromonas gingivalis ATCC 33277 and Porphyromonas endodontalis ATCC 35406 were cultivated in brain heart infusion (BHI) broth (BD Bioscience, Sparks, MD, USA) supplemented with hemin $(1 \mu \mathrm{g} / \mathrm{ml})$ and vitamin $\mathrm{K}(0.2 \mu \mathrm{g} / \mathrm{ml})$ at $37^{\circ} \mathrm{C}$ in an anaerobic chamber. Enterococcus faecalis ATCC 29212 was cultured in $\mathrm{BHI}$ broth at $37^{\circ} \mathrm{C}$ under anaerobic conditions $\left(5 \% \mathrm{H}_{2}, 10 \% \mathrm{CO}_{2}, 85 \% \mathrm{~N}_{2}\right)$. 


\section{Investigation of the antimicrobial activity of the root canal sealers}

The antimicrobial activity of the root canal sealers was investigated according to the methods given by the Clinical Laboratory Standard Institute [34]. The extracts from the root canal sealers after and before setting were filtered using a polyvinylidene fluoride (PVDF) filter (pore size, $0.22 \mu \mathrm{m}$; Millipore Co., Billerica, MA, USA). BHI broth or BHI broth supplemented with hemin and vitamin $\mathrm{K}(180 \mu \mathrm{l})$ was dispensed into each well from the 2 nd to 7 th columns in 96-well polystyrene microplate (SPL Lifescience, Gyeonggi, Republic of Korea), for E. faecalis, or P. gingivalis and P. endodontalis, respectively. The extracts $(180 \mu \mathrm{l})$ were added to the 12 th row wells of the 3rd, 4th, 6th, and 7th column wells of the bacterial medium, and 2-fold serial dilutions were carried out with a multi-channel micropipette. The 2 nd and 5 th column wells of the microplate were controls. The cultured bacteria were counted in a bacterial counting chamber (Marienfeld superior, Lauda-Knigshofen, Germany) and adjusted to $1 \times 10^{6}$ cells $/ \mathrm{ml}$ for E. faecalis and $1.5 \times 10^{6}$ cells $/ \mathrm{ml}$ for $P$. gingivalis and $P$. endodontalis in the respective media. Twenty microliters of the bacterial suspension were inoculated into each well. The microplates were incubated at $37^{\circ} \mathrm{C}$ for $36 \mathrm{~h}$ under anaerobic conditions, and the optical density was measured at $660 \mathrm{~nm}$ using a microplate reader (BioTeck, Winooski, VT, USA) to analyze bacterial growth.

\section{Cell culture and treatment with the root canal sealers}

Pulp cells were isolated from the surface of an extracted third molar and cultivated with Dulbecco's Modified Eagle's medium (DMEM) containing 10\% fetal bovine serum (Hyclone, Logan, UT, USA), $100 \mathrm{U} / \mathrm{ml}$ of penicillin, and $100 \mu \mathrm{g} / \mathrm{ml}$ of streptomycin sulfate (Welgene Inc., Gyeonsangbuk-do, Republic of Korea) at $37^{\circ} \mathrm{C}$ in a $\mathrm{CO}_{2}$ incubator $\left(5 \% \mathrm{CO}_{2}\right.$ conditions). The cells between passages 6 and 9 were seeded at a concentration of $1 \times 10^{5}$ cells $/ \mathrm{ml}$ in each well of a 6 -well polystyrene plate (Corning Co., Corning, NY, USA) until 80\% confluence. After the medium was changed to a serum-free one and incubated at $37^{\circ} \mathrm{C}$ in a $\mathrm{CO}_{2}$ incubator for $4 \mathrm{~h}$ to starve the cells (for inactivation of all signaling pathways), the cells were treated with the extracts of the root canal sealers at various concentrations for $12 \mathrm{~h}$ in a $\mathrm{CO}_{2}$ incubator. The cells were used for RNA extraction and MTT assay, and the conditioned medium was stored at $-80^{\circ} \mathrm{C}$ for ELISA.

\section{Cytotoxicity analysis}

Pulp cells were seeded into the wells of a 96-well poly- styrene microplate (SPL Lifescience, Gyeonggi, Republic of Korea) and incubated until the cells reached $80 \%$ confluence. The cells were treated with the extracts from the root canal sealers after and before setting for $4,8,12,24$, and $48 \mathrm{~h}$. After removing the media, methylthiazolyldiphenyl-tetrazolium bromide (MTT, $4 \mathrm{mg} / \mathrm{ml}$ ) solution was added, and the cells were incubated at $4^{\circ} \mathrm{C}$ for $4 \mathrm{~h}$ in a $\mathrm{CO}_{2}$ incubator. The MTT solution was aspirated, and $100 \mu$ of DMSO was added to the well containing the cells. The microplate was incubated on a shaker to dissolve any crystals that formed in the cells for 30 min at room temperature, and the optical density was measured at a wavelength of $579 \mathrm{~nm}$ using a microplate reader.

\section{Reverse transcription}

The cells treated with the extracts were harvested by centrifugation at $2,000 \times \mathrm{g}$ for $5 \mathrm{~min}$ at $4{ }^{\circ} \mathrm{C}$, and the supernatants were transferred into new $1.5 \mathrm{ml}$ tubes. The cells were treated with $1 \mathrm{ml}$ of TRIzol RNA isolation solution (Invitrogen Life Tech., Carlsbad, CA, USA) and vortexed for $10 \mathrm{~s}$. After adding $200 \mu \mathrm{l}$ of chloroform (Merck, Damstadt, Germany), the prepared tubes were vortexed for $10 \mathrm{~s}$ and centrifuged at $12,000 \times \mathrm{g}$ for $15 \mathrm{~min}$ at $4^{\circ} \mathrm{C}$. The aqueous supernatant $(400 \mu \mathrm{l})$ was transferred into a new $1.5 \mathrm{ml}$ tube and mixed with $900 \mu \mathrm{l}$ of isopropyl alcohol (Merck, Damstadt, Germany). The mixture was incubated for $1 \mathrm{~min}$ at room temperature and centrifuged at $12,000 \times \mathrm{g}$ for $10 \mathrm{~min}$ at $4{ }^{\circ} \mathrm{C}$. After removing the supernatant, $70 \%$ ethyl alcohol in $1 \%$ diethyl pyrocarbonate (DEPC, Sigma-Aldrich Co., St Louis, MO, USA) water was added, and the tube was centrifuged at $12,000 \times \mathrm{g}$ for $10 \mathrm{~min}$ at $4^{\circ} \mathrm{C}$ to harvest the total RNA pellet. The supernatant was removed, and the pellet was dried for $5 \mathrm{~min}$ at room temperature. One hundred microliters of 1\% DEPC water was added, and the RNA pellet dissolved. Total RNA concentration was measured at wavelengths of $260 \mathrm{~nm}$ and $230 \mathrm{~nm}$ using a spectrophotometer (NanoDrop ${ }^{\mathrm{TM}}$, ThermoFisher Scientific, Waltham, MA, USA). Total RNA ( $1 \mu \mathrm{g})$ was mixed with Maxime ${ }^{\mathrm{TM}}$ RT premix containing oligo dT (iNtRON, Gyeonggi, Republic of Korea), and the mixture was incubated for $1 \mathrm{~h}$ at $45^{\circ} \mathrm{C}$ to synthesize cDNA, and for $5 \mathrm{~min}$ at $95^{\circ} \mathrm{C}$ to inactivate reverse transcriptase.

\section{Real time polymerase chain reaction}

The cDNA $(2 \mu \mathrm{l})$ synthesized from the total RNA was mixed with $10 \mu \mathrm{l}$ of SYBR Premix Ex Taq (Takara Co., Kyoto, Japan), $0.2 \mu$ of ROX dye II, and $0.4 \mu \mathrm{M}$ of each primer pair (Table 1), with a final volume of $20 \mu \mathrm{l}$, and 40 PCR cycles were carried out with an ABI 7500 real-time PCR system (Applied Biosystems, Foster City, CA, USA). The cycling conditions were as follows: $95^{\circ} \mathrm{C}$ for $10 \mathrm{~s}, 60^{\circ} \mathrm{C}$ for $15 \mathrm{~s}$, and 
Table 1. The sequence of primers used in this study

\begin{tabular}{lll}
\hline Gene name & \multicolumn{1}{c}{ Sequences } \\
\hline IL-6 & Forward & 3'-AAC CTG TCC ACT GGG CAC A-5' \\
& Reverse & 3'-TCT GGC TCT GAA ACA AAG GAT-5' \\
IL-8 & Forward & 3'-GTG AAG GTG CAG TTT TGC CA-5' \\
& Reverse & 3'-TCT CCA CAA CCC TCT GCA C-5' \\
TNF- $\alpha$ & Forward & 3'-CAG GGA CCT CTC TCT AAT CA-5' \\
& Reverse & 3'-AGC TGG TTA TCT CTC AGC TC-5' \\
GAPDH & Forward & 3'-GTG GTG GAC CTG ACC TGC-5' \\
& Reverse & 3'-TGA GCT TGA CAA AGT GGT CG-5' \\
\hline
\end{tabular}

$72^{\circ} \mathrm{C}$ for $33 \mathrm{~s}$. The PCR products were analyzed for each amplification product using an amplification dissociation curve to confirm non-specific amplification of the product.

Glyceraldehyde-3-phosphate dehydrogenase (GADPH) was used as a housekeeping gene to normalize cytokine expression levels and to quantify changes in expression levels between control and extract-treated cells.

\section{ELISA}

The conditioned cell media treated with the extracts were collected three times during two different experiments and then stored at $-80^{\circ} \mathrm{C}$. After thawing in a deep freezer, the media were centrifuged at $3,000 \times \mathrm{g}$ for $5 \mathrm{~min}$ at $4^{\circ} \mathrm{C}$ to remove debris and cells. The supernatants were transferred into new 1.5 $\mathrm{ml}$ tubes and analyzed for IL-6, IL-8, and TNF- $\alpha$ levels using an ELISA kit (BD Biosciences, San Jose, CA, USA), according to the manufacturer's protocol.

\section{X-ray fluorescence analysis}

When the sealer was set, some reactants were produced from the sealer components. For these reasons, the chemical compositions of the sealers were analyzed using an XRF spectrometer (ZSX Primus II, Rigaku Co., Tokyo, Japan). The sealers were loaded onto micro-carry paper and dried at $55^{\circ} \mathrm{C}$. The XRF spectrometer was outfitted with X-ray tubes with $\mathrm{Rh}$ anodes and operated at $60 \mathrm{kV}$ and $150 \mathrm{~mA}$. The XRF patterns for the sealers were obtained using SC and F-PC diode detectors and analyzed using EZ Scan (Rigaku Co., Tokyo, Japan).

\section{Analysis of surface hardness}

The root canal sealers were dispensed into each well of a 24-well polystyrene plate, and sterile distilled water was dispensed into the outside well of the 24-well plate to support a humidified condition. The plates were incubated at $37^{\circ} \mathrm{C}$ for $48 \mathrm{~h}$ to set the sealers. After extracting the set sealers from the microplate, the surface roughness of the sealers was measured
Table 2. The calculation formula for the Vickers hardness number

\begin{tabular}{cc}
\hline Calculation formula & \multicolumn{1}{c}{ Abbreviation } \\
\hline $\mathrm{VHN}=1.854 \times\left(\mathrm{F} / \mathrm{D}^{2}\right)$ & $\mathrm{F}=$ Load force $(\mathrm{Kgf})$ \\
& $\mathrm{D}=$ Average of diagonals $\left(\mathrm{mm}^{2}\right)$ \\
\hline
\end{tabular}

using a micro Vickers hardness testing machine (HM-200, Mitutoyo, Kawasaki, Japan). Surface particles were removed from the set sealers by air blowing and subjected to a load of $500 \mathrm{gf}$ for $10 \mathrm{~s}$ using a pyramid-shaped diamond indenter. Three indentations were made on the surface of the sealers at separate locations no closer than $5 \mathrm{~mm}$ adjacently. The diagonal resulting indentation was measured using a microscope, and the Vickers hardness value was displayed on the digital readout of the machine. The surface hardness of the sealer was expressed a Vickers hardness number (VHN, $\mathrm{Kg} / \mathrm{mm}^{2}$ ) by calculating the load force and average of the diagonals (Table 2).

\section{Statistical analysis}

Statistical analysis was performed using SPSS 24 (IBM Inc., Chicago, IL, USA). Differences between control and sealer-treated samples were analyzed using the Mann-Whitney test, and differences among each value, including the control, were analyzed using the Kruskal-Wallis test. Statistical significance was set at $\mathrm{p}<0.05$.

\section{Results}

\section{Antimicrobial activity of the root canal sealers}

The antimicrobial activity of the root canal sealers before and after setting were investigated against pulpitis-related bacteria such as E. faecalis, $P$. endodontalis, and P. gingivalis. The extracts of ProRoot and Tubli-Seal before setting showed antimicrobial activity against $E$. faecalis (Figure 1A). ProRoot extract, before setting, significantly exhibited antimicrobial activity against $E$. faecalis at or above a concentration of 25 $\mathrm{mg} / \mathrm{ml}(\mathrm{p}<0.05)$, and Tubli-Seal extract, before setting, significantly showed antimicrobial activity against $E$. faecalis at or above $50 \mathrm{mg} / \mathrm{ml}(\mathrm{p}<0.05)$. In addition, the extracts of both sealers after setting showed similar antimicrobial activity against $E$. faecalis at $100 \mathrm{mg} / \mathrm{ml}$ (Figure 1B). When comparing the antimicrobial activity of both sealers, ProRoot had more antimicrobial activity against $E$. faecalis compared to Tubli-Seal.

In the case of $P$. endodontalis, the extracts from both sealers before setting had comparable antimicrobial activity (Figure 2A). The extracts showed antimicrobial activity against $P$. en- 

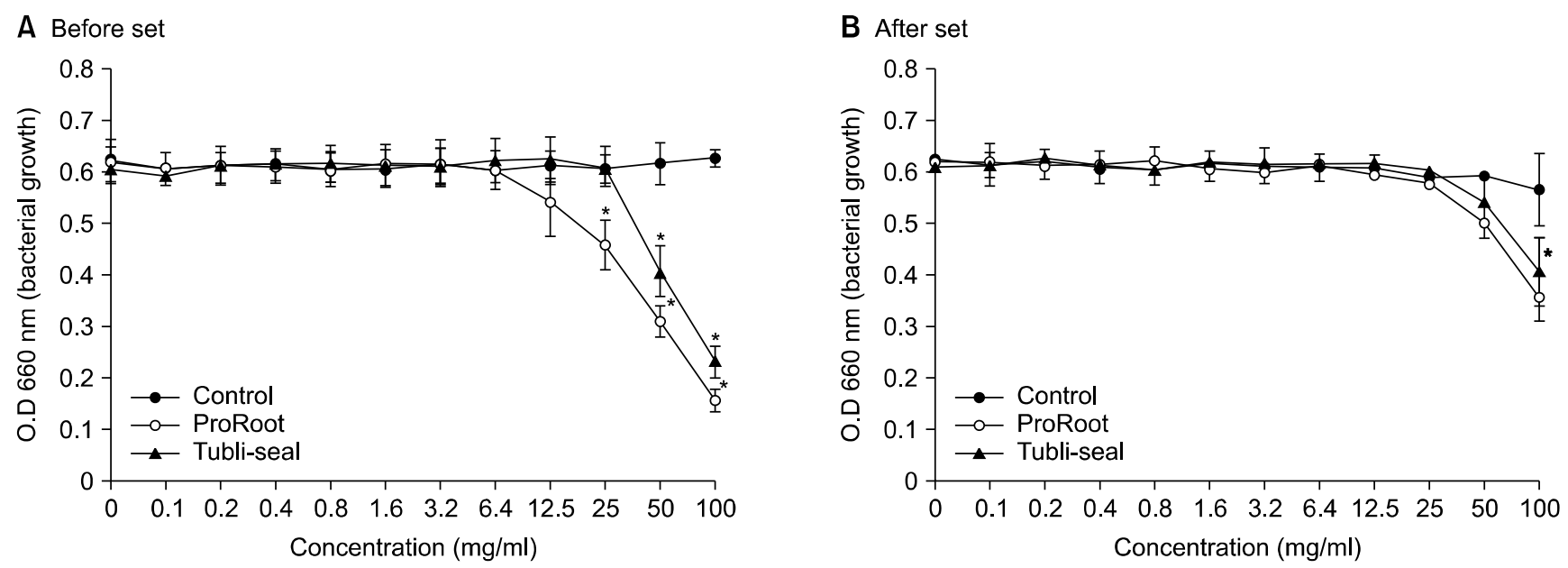

Figure 1. The antimicrobial activity of the root canal sealers against $E$. faecalis. The susceptibility assay of $E$. faecalis was carried out using extracts from ProRoot and Tubli-Seal before or after setting. The bacterial growth was measured at $660 \mathrm{~nm}$ wavelength by a spectrophotometer. ${ }^{*}$ Indicates significant difference compared with control $(p<0.05)$.
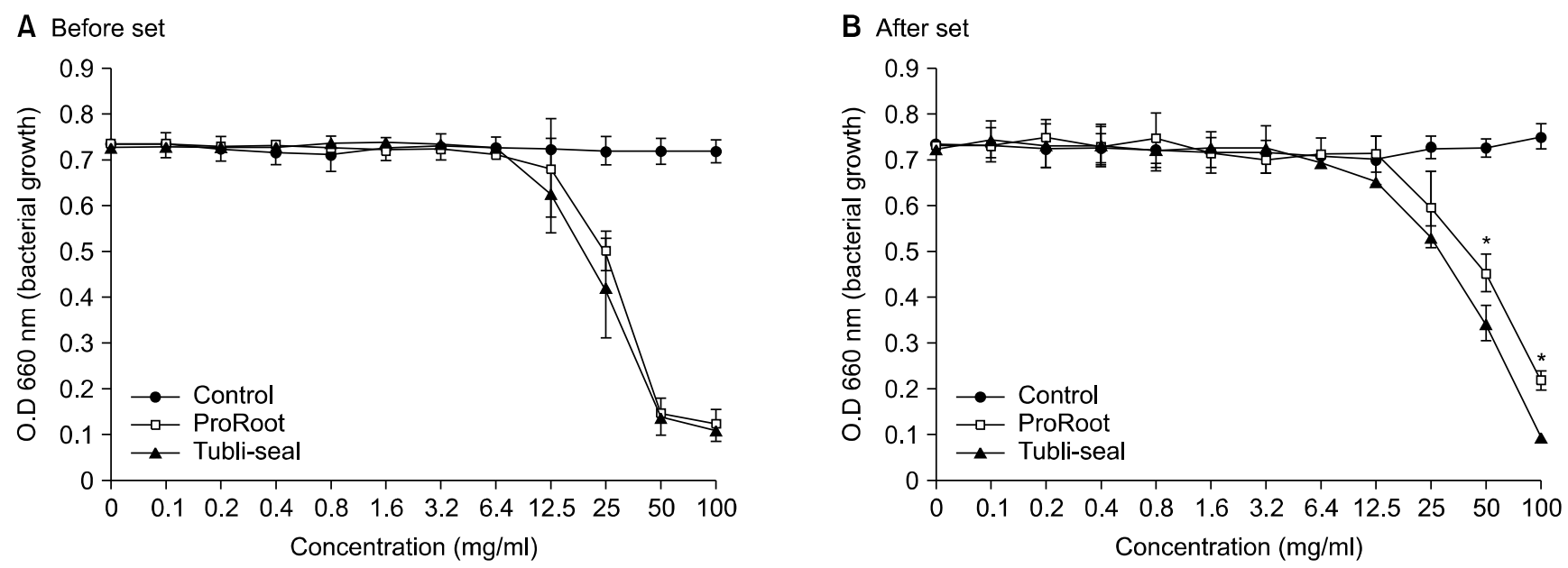

Figure 2. The antimicrobial activity of the root canal sealers against $P$. endodontalis. $P$. endodontalis was treated with the extracts from ProRoot and Tubli-Seal before or after setting and incubated for $36 \mathrm{~h}$. The bacterial growth was measured at $660 \mathrm{~nm}$ wavelength by a spectrophotometer. ${ }^{*}$ Indicates significant difference compared with control $(p<0.05)$.

dodontalis at or above a concentration of $12.5 \mathrm{mg} / \mathrm{ml}$ and significantly inhibited the growth of $P$. endodontalis at concentrations above $25 \mathrm{mg} / \mathrm{ml}(\mathrm{p}<0.05)$. In addition, the antimicrobial activity of the extracts from both sealers after treatment with $P$. endodontalis exhibited a similar pattern (Figure 2B). Although the difference in antimicrobial activity was not significant, the antimicrobial activity of the sealers after setting was at or above a concentration of $25 \mathrm{mg} / \mathrm{ml}$.

When the susceptibility of $P$. gingivalis for the sealer was analyzed, the extracts from ProRoot and Tubli-Seal before setting had antimicrobial activity against $P$. gingivalis at a concentration of $12.5 \mathrm{mg} / \mathrm{ml}$ (Figure $3 \mathrm{~A}$ ), and the extracts from after setting significantly exhibited antimicrobial activity against $P$. gingivalis at or above $50 \mathrm{mg} / \mathrm{ml}$ (Figure 3B). In particular, the extracts from ProRoot and Tubli-Seal before and after setting did not differ significantly in antimicrobial activity against this bacterium, as shown in Figure 3.

\section{Cytotoxicity assay of the root canal sealers}

The cytotoxicity of the root canal sealers was investigated in terms of the bactericidal concentration. Pulp cells were treated with the extracts for $24 \mathrm{~h}$ and $48 \mathrm{~h}$ at concentrations of $12.5 \mathrm{mg} / \mathrm{ml}$ and $25 \mathrm{mg} / \mathrm{ml}$. ProRoot did not affect cell viability (Figure 4). However, Tubli-Seal significantly reduced cell viability at a concentration of $25 \mathrm{mg} / \mathrm{ml}$ at $24 \mathrm{~h}$ and at concentrations of $12.5 \mathrm{mg} / \mathrm{ml}$ and $25 \mathrm{mg} / \mathrm{ml}$ at $48 \mathrm{~h}$. 

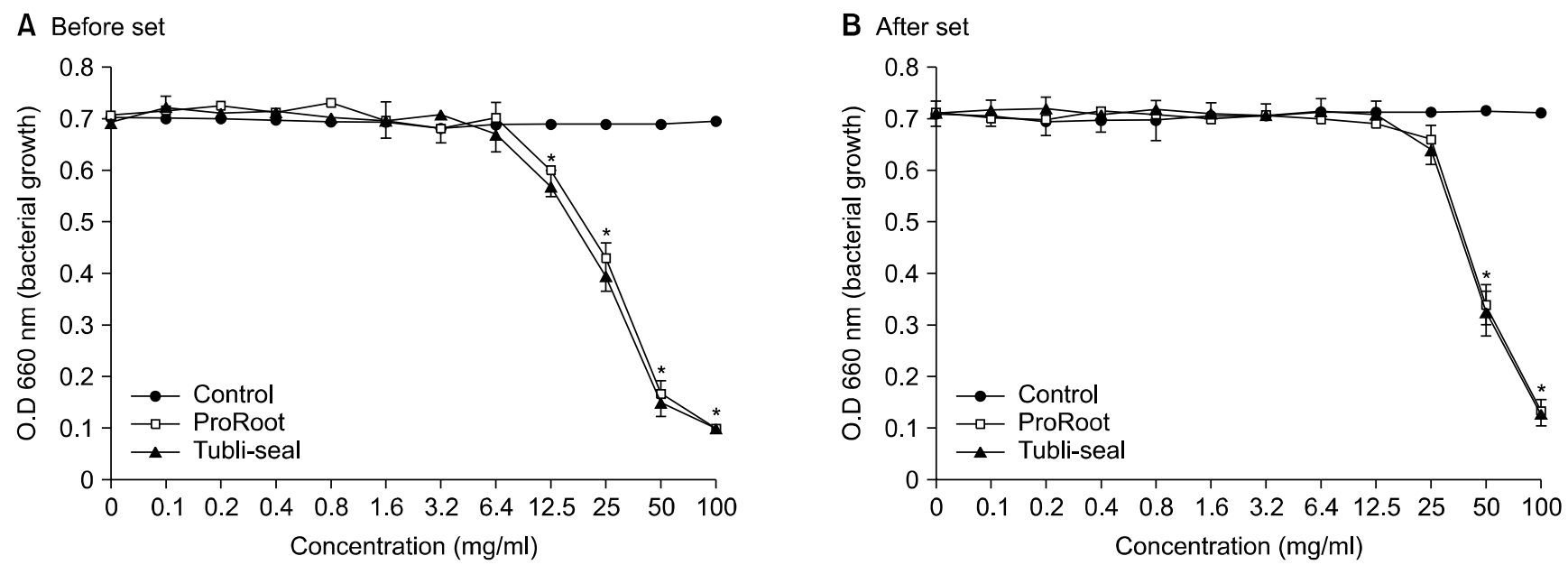

Figure 3. The antimicrobial activity of the root canal sealers against $P$. gingivalis. The extracts from ProRoot and Tubli-Seal before or after setting were was investigated for antimicrobial activity against $P$. gingivalis according to CLSI methods. The bacterial growth was measured at a wavelength of $660 \mathrm{~nm}$ by a spectrophotometer. ${ }^{*}$ Indicates significant difference compared with control $(p<0.05)$.

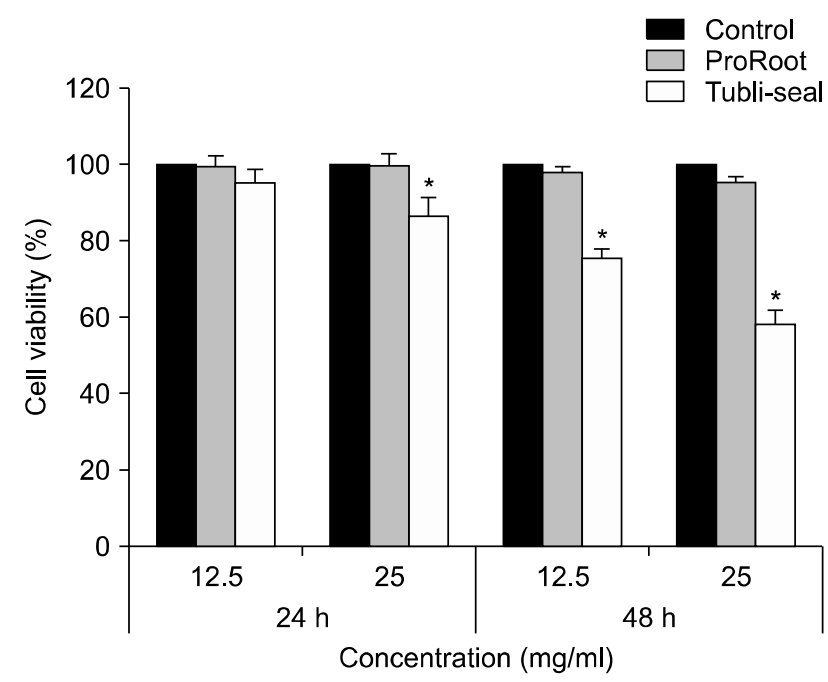

Figure 4. The investigation of cell viability with root canal sealers. The cells were placed into wells of a 96-well plate and treated with the root canal sealers in various concentrations. The cell viability was measured using MTT reagent and a spectrophotometer. *Indicates significant difference compared with control $(\mathrm{p}<0.05)$.

\section{Examining inflammatory cytokine induction by root canal sealers}

Although the root canal sealers did not affect cell viability at low concentrations, the induction of inflammatory cytokines was investigated to confirm whether the sealers stimulated the cells. The pulp cells were treated with the extracts from the sealers, and the induction of inflammatory cytokines was investigated by real-time RT-PCR and ELISA for gene and protein levels, respectively. The extract from ProRoot before setting did not significantly induce the expression of in- flammatory cytokines in pulp cells at concentrations of 3.1 $\mathrm{mg} / \mathrm{ml}$ and $6.2 \mathrm{mg} / \mathrm{ml}$. However, the extract from Tubli-Seal before setting significantly induced the expression of inflammatory cytokines such as TNF- $\alpha$, IL-6, and IL-8 at concentrations of $3.1 \mathrm{mg} / \mathrm{ml}$ and $6.2 \mathrm{mg} / \mathrm{ml}$ (Figure 5)

In addition, when cytokine production was investigated by ELISA, ProRoot weakly induced the production of TNF- $\alpha$, IL-6, and IL-8, whereas Tubli-seal significantly induced the production of cytokines (Figure 6). Tubli-Seal significantly induced the production of TNF- $\alpha$, IL-6, and IL-8, at $3.1 \mathrm{mg} / \mathrm{ml}$ and $6.2 \mathrm{mg} / \mathrm{ml}(\mathrm{p}<0.05)$, and ProRoot slightly induced the production of TNF- $\alpha$, IL-6, and IL-8 at $6.2 \mathrm{mg} / \mathrm{ml}$.

\section{The analysis of components of the root canal sealers using XRF analysis}

ProRoot and Tubli-seal showed differences in antimicrobial activity and cytotoxicity. Therefore, the components of both sealers were analyzed to investigate the causes of these differences. As shown in Table 3, ProRoot has more metal oxide components than Tubli-Seal. Calcium oxide and zinc oxide were the major components of ProRoot and Tubli-Seal, respectively. However, neither sealer had any cytotoxic components in the XRF analysis.

\section{Analysis of surface hardness of the root canal sealers}

Sealing of the root canal system is important for successful root canal therapy as well as for microbial control. Therefore, surface hardness, which is a physical property related to the sealing of the root canal, was investigated. When the surface hardness of both root canal sealers was analyzed, ProRoot had 

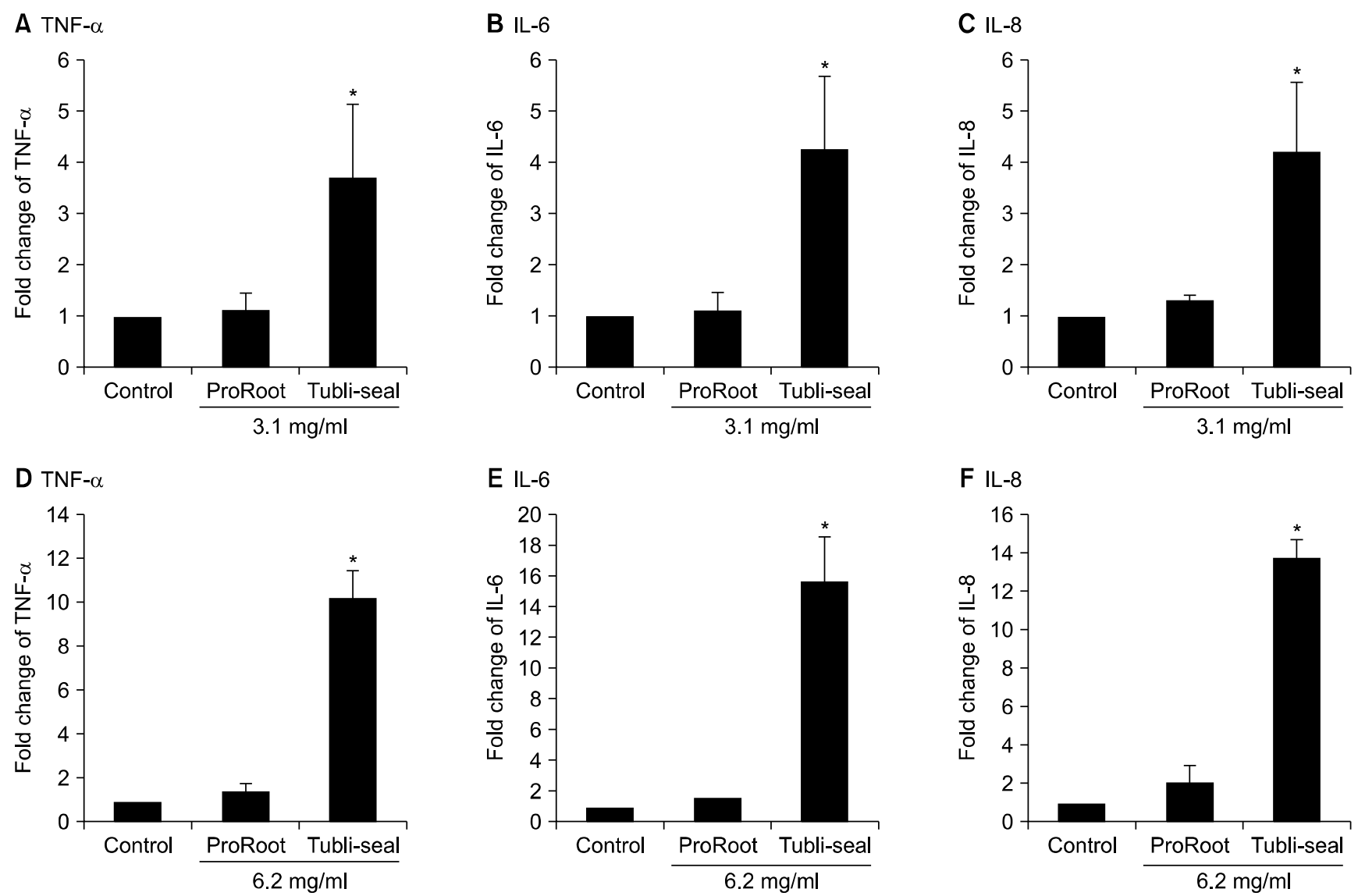

Figure 5. The induction of cytokine expression by root canal sealers. The pulp cells were treated with extracts from ProRoot and Tubli-seal for $12 \mathrm{~h}$ at a concentration of $3.1 \mathrm{mg} / \mathrm{ml}(\mathrm{A}, \mathrm{B}$, and C) and at a concentration of $6.2 \mathrm{mg} / \mathrm{ml}(\mathrm{D}, \mathrm{E}$, and F). After total RNA extraction, real-time RT-PCR was carried out. *Indicates significant difference compared with control $(p<0.05)$.

a harder surface than Tubli-Seal (Table 4). The surface hardness of ProRoot and Tubli-Seal were $47.29 \pm 1.03 \mathrm{Kgf} / \mathrm{mm}^{2}$ and $20.73 \pm 0.30 \mathrm{Kgf} / \mathrm{mm}^{2}$, respectively. These data indicate that the sealing efficacy of ProRoot is higher than that of Tubli-Seal.

\section{Discussion}

Most microbial infections in the root canal system occur and progress after exposure to the oral environment by tooth cracks, tooth fractures, and severe caries [2]. In addition, initial infection of the root canal system is associated with $P$. endodontalis and $P$. gingivalis, and reinfection after treatment is associated with $E$. faecalis $[24,35]$. To eliminate bacterial infection in the root canal, the root canal system is cleaned with $\mathrm{NaOCl}$ solution or disinfectant, and the root canal system is filled with various sealers to prevent re-infection with bacteria [36]. However, because the root canal system is anatomically complex, having fins, isthmi, and accessory canals, it is difficult to completely remove microbes in the root canal system
[7]. Therefore, the use of root canal sealers with antimicrobial activity may help prevent bacterial infection and therapeutic failure. This study investigated and compared the antimicrobial activity of ZOE-based and MTA-based root canal sealers against pulpitis-related bacteria such as $P$. endodontalis, $P$. gingivalis, and E. faecalis. In addition, the cytotoxicity of the sealers towards human pulp cells and the surface hardness after setting the sealers were examined.

The growth of $E$. faecalis as a gram-positive bacterium was inhibited more by ProRoot, an MTA-based sealer, compared with Tubli-seal, a ZOE-based sealer. In the case of gram-negative bacteria such as $P$. endodontalis and $P$. gingivalis, the difference in inhibitory effects between both sealers was not significant. These results indicate that MTA-based sealers have a greater inhibitory effect on gram-positive bacteria than ZOE-based sealers. To evaluate the antimicrobial persistence of the sealers, after setting the sealers, we immersed the sealers in PBS to elute the components, and then examined antimicrobial activity using the eluted matter. Even though the antimicrobial activity of the sealers after setting was com- 

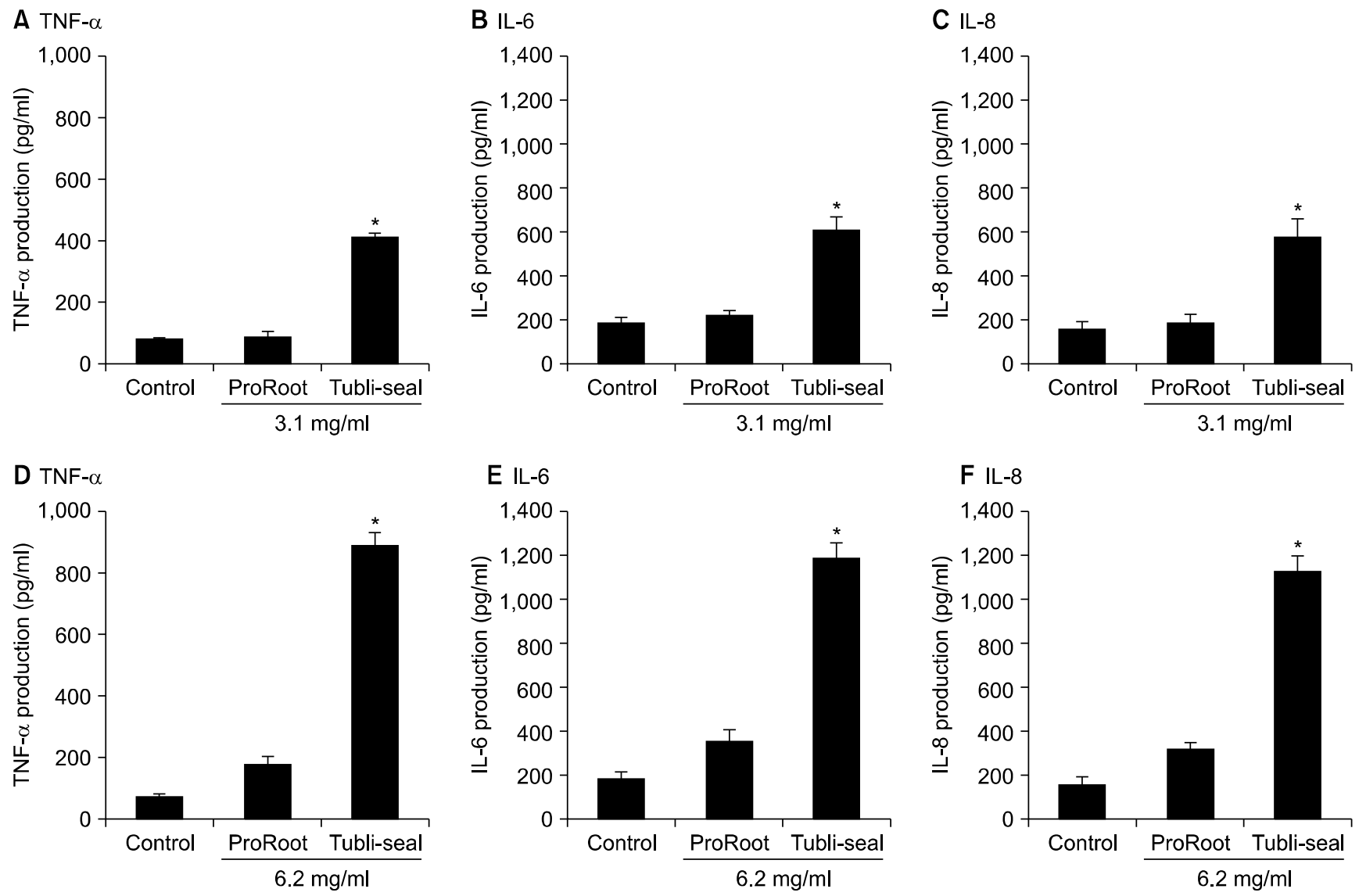

Figure 6. The induction of cytokine production by root canal sealers. The pulp cells were treated with extracts from ProRoot and Tubli-seal for $12 \mathrm{~h}$ at a concentration of $3.1 \mathrm{mg} / \mathrm{ml}(\mathrm{A}, \mathrm{B}$, and C) and at a concentration of $6.2 \mathrm{mg} / \mathrm{ml}(\mathrm{D}, \mathrm{E}$, and F). After collecting the conditioned media, ELISA was carried out according to the manufacturer's protocol. ${ }^{*}$ Indicates significant difference compared with control $(p<0.05)$.

Table 3. Component analysis of ProRoot and Tubli-Seal by X-ray fluorescence analysis

\begin{tabular}{|c|c|c|c|}
\hline \multicolumn{2}{|c|}{ ProRoot } & \multicolumn{2}{|c|}{ Tubli-Seal } \\
\hline Components & Mass $\%$ & Components & Mass $\%$ \\
\hline $\mathrm{Al}_{2} \mathrm{O}_{3}$ & 1.73 & $\mathrm{BaO}$ & 4.58 \\
\hline $\mathrm{Bi}_{2} \mathrm{O}_{3}$ & 14.32 & $\mathrm{CaO}$ & 0.02 \\
\hline $\mathrm{CaO}$ & 63.32 & 1 & 1.57 \\
\hline $\mathrm{Fe}_{2} \mathrm{O}_{3}$ & 0.31 & $\mathrm{~K}_{2} \mathrm{O}$ & 0.05 \\
\hline $\mathrm{K}_{2} \mathrm{O}$ & 0.06 & $\mathrm{NiO}$ & 0.01 \\
\hline $\mathrm{MgO}_{3}$ & 0.71 & $\mathrm{P}_{2} \mathrm{O}_{5}$ & 0.07 \\
\hline $\mathrm{MnO}$ & 0.02 & $\mathrm{SO}_{3}$ & 2.16 \\
\hline $\mathrm{Na}_{2} \mathrm{O}$ & 0.14 & $\mathrm{SrO}$ & 0.02 \\
\hline $\mathrm{NiO}$ & 0.02 & $\mathrm{ZnO}$ & 91.52 \\
\hline $\mathrm{P}_{2} \mathrm{O}_{5}$ & 0.24 & & \\
\hline $\mathrm{SiO}_{2}$ & 17.03 & & \\
\hline $\mathrm{SO}_{3}$ & 1.88 & & \\
\hline $\mathrm{SrO}$ & 0.10 & & \\
\hline $\mathrm{TiO}_{2}$ & 0.08 & & \\
\hline $\mathrm{V}_{2} \mathrm{O}_{5}$ & 0.04 & & \\
\hline
\end{tabular}

Table 4. The surface hardness of root canal sealers

\begin{tabular}{cc}
\hline Sealer & VHN $\left(\mathrm{Kg} / \mathrm{mm}^{2}\right)$ \\
\hline ProRoot & $47.29 \pm 1.03$ \\
Tubli-Seal & $20.73 \pm 0.30$ \\
\hline
\end{tabular}

paratively weak, the difference between the sealers showed a similar tendency to that of the sealers before setting. Although ProRoot MTA is only one representative of MTA-based sealers, similar results have been reported in previous studies [37-39]. Therefore, other MTA-based sealers may show similar results to ProRoot MTA.

Among the characteristics of the root canal sealer, biocompatibility is considered to be as important as antimicrobial activity. Therefore, the cytotoxicity of both sealers was investigated using human pulp cells. Pulp cells were treated with Tubli-seal and ProRoot MTA for $24 \mathrm{~h}$ and $48 \mathrm{~h}$, respectively. Tubli-seal exhibited strong cytotoxicity to pulp cells at a concentration of $25 \mathrm{mg} / \mathrm{ml}$ at $24 \mathrm{~h}$ and at $12.5 \mathrm{mg} / \mathrm{ml}$ and $25 \mathrm{mg} / \mathrm{ml}$ at $48 \mathrm{~h}$. However, ProRoot MTA did not show cytotoxicity. 
When human lung fibroblasts are treated with zinc oxide nanoparticles, zinc oxide induces oxidative stress-related cytotoxicity and genotoxicity [40]. Furthermore, eugenol is cytotoxic to human osteoblastic cell line A, and cytotoxicity has been reported [41]. Based on these data, it is reasonable that ZOE-based sealers are cytotoxic to human pulp cells.

Since ProRoot, an MTA-based sealer, did not show cytotoxicity in this study, we carried out an experiment to determine whether ProRoot induces the expression of inflammatory cytokines. ProRoot slightly induced the expression of inflammatory cytokines at a concentration of $6.2 \mathrm{mg} / \mathrm{ml}$, and Tubli-seal strongly induced the expression of cytokines at concentrations of $3.1 \mathrm{mg} / \mathrm{ml}$ and $6.2 \mathrm{mg} / \mathrm{ml}$. Although strong induction of inflammatory cytokines is related to tissue destruction and induction of inflammation, weak induction of inflammatory cytokines helps regenerate wound healing $[42,43]$. Therefore, ProRoot may help regenerate pulpal tissue impaired by inflammation or bacterial infection.

Finally, the components of ProRoot and Tubli-Seal were analyzed using XRF analysis. Tubli-seal showed $\mathrm{ZnO}$ as a major component, and ProRoot was composed of three major components: $\mathrm{CaO}, \mathrm{SiO}_{2}$, and $\mathrm{Bi}_{2} \mathrm{O}_{3}$.

Metal oxides exhibit strong antimicrobial activity [44]. In this case, Tubli-seal has ZnO-related antimicrobial activity, whereas ProRoot showed antimicrobial effects by various metal oxides.

In conclusion, the best root canal sealer material must have antimicrobial activity against pulpitis-related bacteria and biocompatibility to pulpal tissue. ProRoot, an MTA-based sealer, exhibited antimicrobial activity against $E$. faecalis, $P$. endodontalis, and $P$. gingivalis, with no cytotoxicity. Therefore, MTA-based sealers may be a more suitable material for root canal therapy than ZOE-based sealers.

\section{Conclusion}

Pulpitis is induced by microbial infection in the root canal system. To treat pulpitis, the root canal system is cleaned with disinfectants, and a root canal sealer is inserted to prevent re-infection. Anatomically, because the root canal system is complicated, microorganisms are not easily removed by disinfectants. Therefore, root canal sealers with antimicrobial activities are required. The aim of this study was to investigate the antimicrobial activity and cytotoxicity of ZOE-based and MTA-based root canal sealers.

The root canal sealers used in this study were Tubli-Seal, a ZOE-based sealer, and ProRoot, an MTA-based sealer. The antimicrobial activity of ProRoot and Tubli-seal was assessed by a susceptibility assay using E. faecalis, P. endodontalis, and $P$. gingivalis. The cytotoxicity of the root canal sealers was investigated by MTT assay, real-time RT-PCR, and ELISA after treatment of pulp cells with sealers. Additionally, the components of the root canal sealers were analyzed using XRF analysis.

The MTA-based sealer showed stronger antimicrobial activity against $E$. faecalis than the ZOE-based sealer, and the antimicrobial activity of both sealers against $P$. endodontalis and $P$. gingivalis showed no significant difference. The ZOE-based sealer showed strong cytotoxicity towards pulp cells and induced the expression and production of inflammatory cytokines. However, the MTA-based sealer did not affect the viability of pulp cells or significantly induce the expression of inflammatory cytokines such as TNF- $\alpha$, IL-6, and IL-8. On component analysis, MTA-based sealers were found to have more kinds of metal oxides than ZOE-based sealers.

In conclusion, the MTA-based sealer had stronger antimicrobial activity against E. faecalis compared to the ZOEbased sealer, and did not show significant cytotoxicity towards pulp cells. Based on these results, MTA-based sealers may be a suitable material for root canal therapy.

\section{Conflict of Interest}

No potential conflict of interest relevant to this article was reported.

\section{ORCID}

Seok-Eun Lee, https://orcid.org/0000-0003-3792-8120

Ja-Won Cho, https://orcid.org/0000-0003-1458-0416

Hyun-Jun Yoo, https://orcid.org/0000-0002-0100-8309

Myung-Gu Lee, https://orcid.org/0000-0002-0068-1438

Yeol-Mae Jeon, https://orcid.org/0000-0002-9700-9137

Da-Hui Kim, https://orcid.org/0000-0003-0226-0212

Hye-Won Park, https://orcid.org/0000-0001-9590-2442

\section{References}

1. Sakko M, Tjäderhane L, Rautemaa-Richardson R. Microbiology of root canal infections. Prim Dent J 2016;5:84-9.

2. Sadasiva K, Ramalingam S, Rajaram K, Meiyappan A. Cracked tooth syndrome: a report of three cases. J Pharm Bioallied Sci 2015;7(Suppl 2):S700-3.

3. Rollison S, Barnett F, Stevens RH. Efficacy of bacterial removal from instrumented root canals in vitro related to instrumentation technique and size. Oral Surg Oral Med Oral Pathol Oral Radiol Endod 2002;94:366-71.

4. Peters OA. Current challenges and concepts in the preparation 
of root canal systems: a review. J Endod 2004;30:559-67.

5. Bender IB. Reversible and irreversible painful pulpitides: diagnosis and treatment. Aust Endod J 2000;26:10-4.

6. Molander A, Reit C, Dahlén G, Kvist T. Microbiological status of root-filled teeth with apical periodontitis. Int Endod J 1998; 31:1-7.

7. Chang SW, Lee JK, Lee Y, Kum KY. In-depth morphological study of mesiobuccal root canal systems in maxillary first molars: review. Restor Dent Endod 2013;38:2-10.

8. Fouad AF, Zerella J, Barry J, Spångberg LS. Molecular detection of Enterococcus species in root canals of therapy-resistant endodontic infections. Oral Surg Oral Med Oral Pathol Oral Radiol Endod 2005;99:112-8.

9. Limkangwalmongkol S, Burtscher P, Abbott PV, Sandler AB, Bishop BM. A comparative study of the apical leakage of four root canal sealers and laterally condensed gutta-percha. J Endod 1991;17:495-9.

10. Al-Haddad A, Che Ab Aziz ZA. Bioceramic-based root canal sealers: a review. Int J Biomater 2016;2016:9753210.

11. Huffman BP, Mai S, Pinna L, Weller RN, Primus CM, Gutmann JL, et al. Dislocation resistance of ProRoot Endo Sealer, a calcium silicate-based root canal sealer, from radicular dentine. Int Endod J 2009;42:34-46.

12. Zare Jahromi M, Navabi AA, Ekhtiari M. Comparing coronal discoloration between AH26 and ZOE sealers. Iran Endod J 2011;6:146-9.

13. Mahdi AA, Bolaños-Carmona V, Gonzalez-Lopez S. Bond strength to root dentin and fluid filtration test of AH Plus/gutta-percha, EndoREZ and RealSeal systems. J Appl Oral Sci 2013;21:369-75.

14. Shakya VK, Gupta P, Tikku AP, Pathak AK, Chandra A, Yadav RK, et al. An invitro evaluation of antimicrobial efficacy and flow characteristics for AH Plus, MTA Fillapex, CRCS and Gutta Flow 2 root canal sealer. J Clin Diagn Res 2016;10: ZC104-8.

15. Chang SW, Lee YK, Zhu Q, Shon WJ, Lee WC, Kum KY, et al. Comparison of the rheological properties of four root canal sealers. Int J Oral Sci 2015;7:56-61.

16. Javidi M, Zarei M, Naghavi N, Mortazavi M, Nejat AH. Zinc oxide nano-particles as sealer in endodontics and its sealing ability. Contemp Clin Dent 2014;5:20-4.

17. Nomura K, Ohta H, Ueda K, Kamiya T, Hirano M, Hosono H. Thin-film transistor fabricated in single-crystalline transparent oxide semiconductor. Science 2003;300:1269-72.

18. Gajjar P, Pettee B, Britt DW, Huang W, Johnson WP, Anderson AJ. Antimicrobial activities of commercial nanoparticles against an environmental soil microbe, Pseudomonas putida KT2440. J Biol Eng 2009;3:9.

19. Hajipour MJ, Fromm KM, Ashkarran AA, Jimenez de Aberasturi D, de Larramendi IR, Rojo T, et al. Antibacterial properties of nanoparticles. Trends Biotechnol 2012;30:499-511.

20. Bezerra DP, Militão GCG, de Morais MC, de Sousa DP. The dual antioxidant/prooxidant effect of eugenol and its action in cancer development and treatment. Nutrients 2017;9:1367.

21. Bevilacqua A, Corbo MR, Sinigaglia M. In vitro evaluation of the antimicrobial activity of eugenol, limonene, and citrus extract against bacteria and yeasts, representative of the spoiling microflora of fruit juices. J Food Prot 2010;73:888-94.

22. Camilleri J. The chemical composition of mineral trioxide aggregate. J Conserv Dent 2008;11:141-3.

23. Camilleri J, Montesin FE, Brady K, Sweeney R, Curtis RV, Ford TR. The constitution of mineral trioxide aggregate. Dent Mater 2005;21:297-303.

24. Gomes BP, Pinheiro ET, Gadê-Neto CR, Sousa EL, Ferraz CC, Zaia AA, et al. Microbiological examination of infected dental root canals. Oral Microbiol Immunol 2004;19:71-6.

25. Sundqvist G. Ecology of the root canal flora. J Endod 1992;18: 427-30.

26. Darveau RP, Tanner A, Page RC. The microbial challenge in periodontitis. Periodontol 2000 1997;14:12-32.

27. Potempa J, Pavloff N, Travis J. Porphyromonas gingivalis: a proteinase/gene accounting audit. Trends Microbiol 1995;3:430-4.

28. Petit MD, van Winkelhoff AJ, van Steenbergen TJ, de Graaff J. Porphyromonas endodontalis: prevalence and distribution of restriction enzyme patterns in families. Oral Microbiol Immunol 1993;8:219-24.

29. Hanazawa S, Sagiya T, Kitami H, Ohta K, Nishikawa H, Kitano S. Monoclonal antibody against Porphyromonas (Bacteroides) endodontalis lipopolysaccharide and application of the antibody for direct identification of the species. J Clin Microbiol 1991; 29:2550-3.

30. Yamazaki K, Ikarashi F, Aoyagi T, Takahashi K, Nakajima T, Hara K, et al. Direct and indirect effects of Porphyromonas gingivalis lipopolysaccharide on interleukin- 6 production by human gingival fibroblasts. Oral Microbiol Immunol 1992;7:218-24.

31. Stuart CH, Schwartz SA, Beeson TJ, Owatz CB. Enterococcus faecalis: its role in root canal treatment failure and current concepts in retreatment. J Endod 2006;32:93-8.

32. Jett BD, Huycke MM, Gilmore MS. Virulence of enterococci. Clin Microbiol Rev 1994;7:462-78.

33. Cosentino S, Podda GS, Corda A, Fadda ME, Deplano M, Pisano MB. Molecular detection of virulence factors and antibiotic resistance pattern in clinical Enterococcus faecalis strains in Sardinia. J Prev Med Hyg 2010;51:31-6.

34. Hecht DW, Citron DM, Cox M, Jacobus N, Jenkins SG, Onderdonk A, et al. Methods for antimicrobial susceptibility testing of anaerobic bacteria: approved standard. 7th ed. Wayne: Clinical and Laboratory Standards Institute; 2007:47.

35. Kim HS, Woo Chang S, Baek SH, Han SH, Lee Y, Zhu Q, et al. Antimicrobial effect of alexidine and chlorhexidine against Enterococcus faecalis infection. Int J Oral Sci 2013;5:26-31.

36. Grischke J, Müller-Heine A, Hülsmann M. The effect of four different irrigation systems in the removal of a root canal sealer. Clin Oral Investig 2014;18:1845-51.

37. Kim RJ, Kim MO, Lee KS, Lee DY, Shin JH. An in vitro evaluation of the antibacterial properties of three mineral trioxide aggregate (MTA) against five oral bacteria. Arch Oral Biol 2015; 60:1497-502.

38. Singh G, Gupta I, Elshamy FMM, Boreak N, Homeida HE. In vitro comparison of antibacterial properties of bioceramic- 
based sealer, resin-based sealer and zinc oxide eugenol based sealer and two mineral trioxide aggregates. Eur J Dent 2016;10: 366-9.

39. Morgental RD, Vier-Pelisser FV, Oliveira SD, Antunes FC, Cogo DM, Kopper PM. Antibacterial activity of two MTA-based root canal sealers. Int Endod J 2011;44:1128-33.

40. Ng CT, Yong LQ, Hande MP, Ong CN, Yu LE, Bay BH, et al. Zinc oxide nanoparticles exhibit cytotoxicity and genotoxicity through oxidative stress responses in human lung fibroblasts and Drosophila melanogaster. Int J Nanomedicine 2017;12:1621-37.

41. Ho YC, Huang FM, Chang YC. Mechanisms of cytotoxicity of eugenol in human osteoblastic cells in vitro. Int Endod J 2006;
39:389-93.

42. Sgonc R, Gruber J. Age-related aspects of cutaneous wound healing: a mini-review. Gerontology 2013;59:159-64.

43. Serra MB, Barroso WA, da Silva NN, Silva SDN, Borges ACR, Abreu IC, et al. From inflammation to current and alternative therapies involved in wound healing. Int J Inflam 2017;2017: 3406215 .

44. Azam A, Ahmed AS, Oves M, Khan MS, Habib SS, Memic A. Antimicrobial activity of metal oxide nanoparticles against Gram-positive and Gram-negative bacteria: a comparative study. Int J Nanomedicine 2012;7:6003-9. 